\title{
SELF-CONFIDENCE AND LEARNING OUTCOMES OF STUDENTS IN FLIPPED CLASSROOM ON CELL LEARNING
}

\author{
Muhibbuddin $^{1 *}$, Puput Marlisa ${ }^{2}$, \& Hafnati Rahmatan ${ }^{3}$ \\ ${ }^{1}$ Dr., Universitas Syiah Kuala, Banda Aceh, Indonesia, muhibbuddin@unsyiah.ac.id \\ ${ }^{2}$ Universitas Syiah Kuala, Banda Aceh, Indonesia, puputmarlisa.mpbio17@edu.unsyiah.ac.id \\ ${ }^{3}$ Dr., Universitas Syiah Kuala, Banda Aceh, Indonesia, hafnati_rahmatan@unsyiah.ac.id \\ "Corresponding Author
}

\begin{abstract}
Self-confidence is an important construct for students. Some studies show the low self-confidence will effect on learning outcomes. A learning strategy is needed to solve the problem about self-confidence and learning outcomes of students. This research aims to determine the effect of flipped classroom on self-confidence and learning outcomes. Experimental method was used in this study with a pre-test, post test control group design. One hundred sixty-five students were participated in this study; they were randomly divided into two groups: an experimental group (flipped classroom) consists eighty-four students and a control group (conventional classroom) consists eighty-one students. This study was conducted at three high schools in West Aceh Regency, Aceh, Indonesia. This study took two months from July to August 2019. The parameter measured for data collection in this study was self-confidence and learning outcomes of students. Selfconfidence and learning outcomes data were analysed using parametric statistics with independent sample $\mathrm{t}$-tests and to see the correlation of self-confidence to learning outcomes was known through correlation and regression analysis. The results showed a significant difference on self-confidence and learning outcomes of students between experimental group and control group. The correlation coefficient showed a positive and strong relationship between self-confidence and learning outcomes $(r=0.796)$, self-confidence contributed $63 \%$ to learning outcomes. The results revealed that the implementation of flipped classroom can promote self-confidence and learning outcomes.
\end{abstract}

Keywords: Flipped Classroom, Self-confidence, Learning outcomes.

\section{INTRODUCTION}

Self-confidence can be called as an important construct for students (Maclellan, 2014). It is a concept that refers to hope, optimism, certainty, trust and attitude (Oney and Oksuzoglu-Guven, 2015). Student with good Self-confidence in learning process can believe in their own ability on asking question, discussion, giving opinions and initiative on learning.

Previous studies Everingham et al. (2017) and Telbis et al. (2014) have revealed that students who have the low level in Self-confidence will impact on learning outcomes. The results of observation at several senior high schools in West Aceh Regency showed that the Self-confidence of students in the learning process was still low, especially in terms of asking questions. Students tend to follow their friends' answer when answering teacher questions and it impacted on learning outcomes showed that $70 \%$ of students are below 
the minimum completeness criteria.

The results of interviews with several students in senior high schools in West Aceh Regency showed that students were not sure about their answers to the questions asked by the teacher. The learning process in class did not get the maximum results. In addition, in completing tasks (homework) was also often completed outside of the specified time. These things indicated students' confidence in their abilities and responsibilities were still low. While the results of interviews with biology teacher also revealed that the teaching materials used were textbooks and the teacher usually did not emphasize students to study before attending in the class.

There are many educational implications in learning for students. Modern learning that is combined with real practice in the classroom is very important in developing student's confidence (Malandrakis, 2018). One of the ways that can be used by teachers in increasing student's confidence and learning outcomes is by using flipped classroom learning (Jones et al., 2019).

Flipped Classroom is a learning process that reduces the capacity of learning activities in the classroom by maximizing interaction with each other such as the teacher, students and their environment (Johnson and Graham, 2013). Flipped classroom is a learning strategy where in the teaching and learning process is not like in conventional, the students are introduced to the learning material at home through online video before learning in class, with classroom time then being used to doing assignments, discussing material or problems that are not understood by students.

Several studies has investigated the effect of flipped classroom in learning process (Brown et al., 2016; Youngkin, 2014; Hung, 2015; Zarrinabadi and Ebrahimi, 2019; Naccarato and Karakok, 2015; Kim, 2017; Rivera, 2017; Lax et al., 2017; Chen-Hsieh et al., 2017; Balaban et al., 2016; McLaughlin et al., 2016; Adnan, 2017 and Haghighi et al., 2019; Zarrinabadi and Ebrahimi, 2019), the results of these studies only revealed the implementation of flipped classroom on speaking skill, motivation, learning outcomes, students' participationt, students' activity and interaction on students. Although numerous studies have inspected about implementation of flipped classroom, it is still a small number about investigate the effect of flipped classroom on Self-confidence and how Self-confidence contributes to learning outcomes. Therefore, this study was conducted to determine the effect of the application of flipped classroom on Self-confidence and learning outcomes.

\section{RESEARH METHOD}

This research used experiment method with pre-test post-test control group design (Gall et al., 2003). The detail of research design can be seen in Table 1 (Table-1).

Table-1. Pre-test post-test Control Group Design

\begin{tabular}{|c|c|c|c|c|}
\hline Sample & Classes & Pre-test & Treatments & Post test \\
\hline Random & Experiment & $\mathrm{O}_{1}$ & $\mathrm{P}_{1}$ & $\mathrm{O}_{2}$ \\
\hline Random & Control & $\mathrm{O}_{3}$ & - & $\mathrm{O}_{4}$ \\
\hline
\end{tabular}

Information:

O1 : Pre-test before treatments is given to class of experiment

O2 : post-test after treatments is given to class of experiment

O3 : Pre-test before treatments is given to class of control

O4 : post test after treatments is given to class of control

$P_{1}$ : Treatments to class of experiment

Participants of this study included 165 students enrolled in high school (SMA), they were randomly divided into two groups: experimental group (flipped classroom learning) and control group (conventional learning). There were 84 students in the experimental group and 81 students in the control group. This research was conducted in the first semester of academic year 2019, which ran from July-August 2019 in Meulaboh, West Aceh Regency, Aceh, Indonesia.

The parameters measured for data collection are Self-confidence and learning outcomes. Self-confidence was measured by using a questionnaire with five aspects, they are: belief in own abilities, optimistic, 
objective, responsible and rational. Learning outcomes was measured using a multiple choice test with four answer choices. Self-confidence data were obtained after treatment in both groups, while learning outcomes data was obtained through pre-test and post test.

\section{DATA AND ANALYSIS}

Self-confidence data was analysed through a percentage of aspects of Self-confidence. The results of the analysis are grouped into five categories: (1) very low $0 \%-20 \%$, (2) low $21 \%-40 \%$, (3) $41 \%-60 \%$ medium, (4) high $61 \%-80 \%$ and (5) $81 \%-100 \%$ very high. Self-confidence and learning outcomes data were analysed by parametric analysts: normality test, homogeneity test, gain normalization (n-gain) and a mean difference test. A mean difference test used independent sample t-test by comparing the initial ability (the results of the pre-test) and the final ability (n-gain). Meanwhile, to see the correlation of Self-confidence and learning outcomes (post-test) used correlation and regression analysis.

\section{FINDINGS AND DISCUSSION}

\subsection{Self-confidence}

Self-confidence data (Figure-1) showed that students in the experimental group obtained 13 people (16\%) was in very high category, 64 people $(76 \%)$ was in high category and 7 people $(8 \%)$ was in medium category and in the control group 21 people (26\%) was in high category and 60 people (74\%) was in medium category.

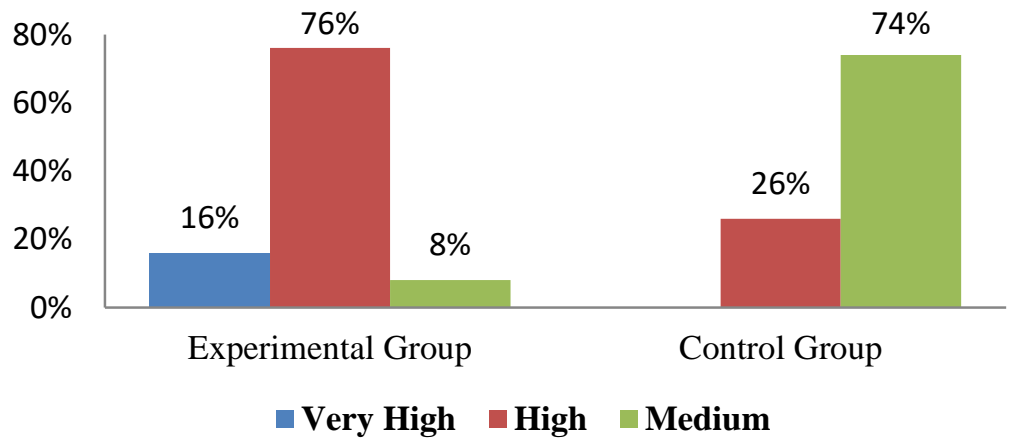

Figure-1. Percentage of Self-confidence category

The data of Self-confidence by aspect (Figure-2) showed that the Self-confidence in the experimental group was higher than in the control group. In the experimental group all aspects included in the high category and in the control group included in the medium category. The data showed that the highest aspect in the experimental group and the control group was belief in own abilities, it was $75 \%$ in the experimental group and $58 \%$ in the control group. While the lowest aspect in the experimental group was the objective (70\%) and the lowest aspect in the control group was the responsible (54\%).

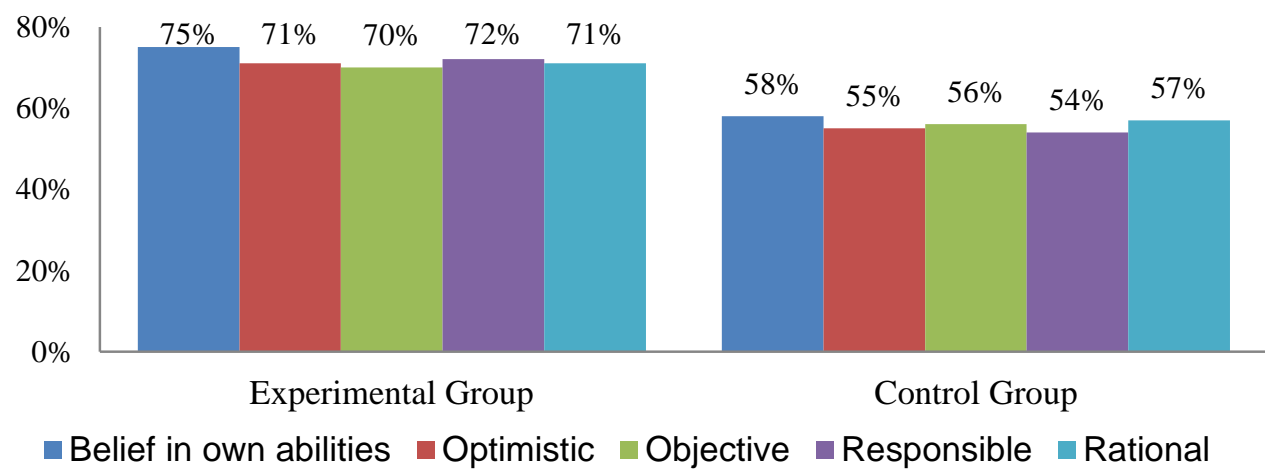

Figure-2. Percentage of aspects of Self-confidence

The compare means t-test showed that a significant difference on Self-confidence data between the experimental group and the control group (Table-2). It can be believed that learning with flipped classroom can promote students' Self-confidence. 
Table-2. The compare means t-test of Self-confidence

\begin{tabular}{|c|c|c|c|c|}
\hline Group & Mean & Normality * & Homogeneity ** & Significance \\
\hline Control & 71,63 & $\begin{array}{c}\text { Normal } \\
X_{\text {count }}^{2}(3,33)<X^{2}{ }_{\text {tab }}(9,48)\end{array}$ & \multirow{2}{*}{ 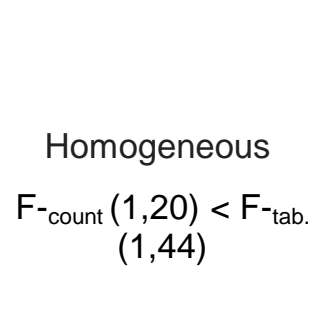 } & \multirow{2}{*}{$\begin{array}{c}\text { Significance Difference } \\
\qquad t^{-}{ }_{\text {count }}(11,28)> \\
t^{-}{ }_{\text {tab }}(1,97)\end{array}$} \\
\hline Experiment & 58,09 & $\begin{array}{c}\text { Normal } \\
X^{2} \text { count }(6,89)<X^{2} \text { tab }(9,48)\end{array}$ & & \\
\hline
\end{tabular}

Information:

* Chi square (Normal; $X_{\text {count }}^{2}<X_{\text {table, }}^{2} \alpha=0,05$ )

${ }^{* *} \mathrm{~F}$-Test (Homogeneous; $\mathrm{F}_{\text {-count }}<\mathrm{F}_{\text {-table, }} \mathrm{\alpha}=0,05$ )

Students in flipped classroom (experimental group) learned the material by watching videos at home before learning classically in class so that students already have an understanding and ability of the material before learning in class. The students in flipped classroom had the advantage about being able to question and answer among students so they could work more efficiently and it made them more confident in learning process (Heuett, 2017).

The research study of Ceylaner and Karakus (2018) revealed that learning in flipped classroom students can choose the environment and the right time to do the learning process independently. In addition, students know what is learned before, during and after learning. In flipped classroom students are required to watch videos before the learning process and other videos after learning. It can be known that in flipped classroom train students to learn independently, so that it can increase Self-confidence.

\subsection{Learning Outcomes}

Student learning outcomes (Figure-3) showed that the initial knowledge (pre-test) of students was very low, with an average score of pre-test was 30.02 in the experimental group and 29.38 in the control group. The post test of the experimental group was higher than the control group. Learning outcomes enhancement $(\mathrm{n}$ gain) showed the experimental group was in high category and the control group in the medium category.

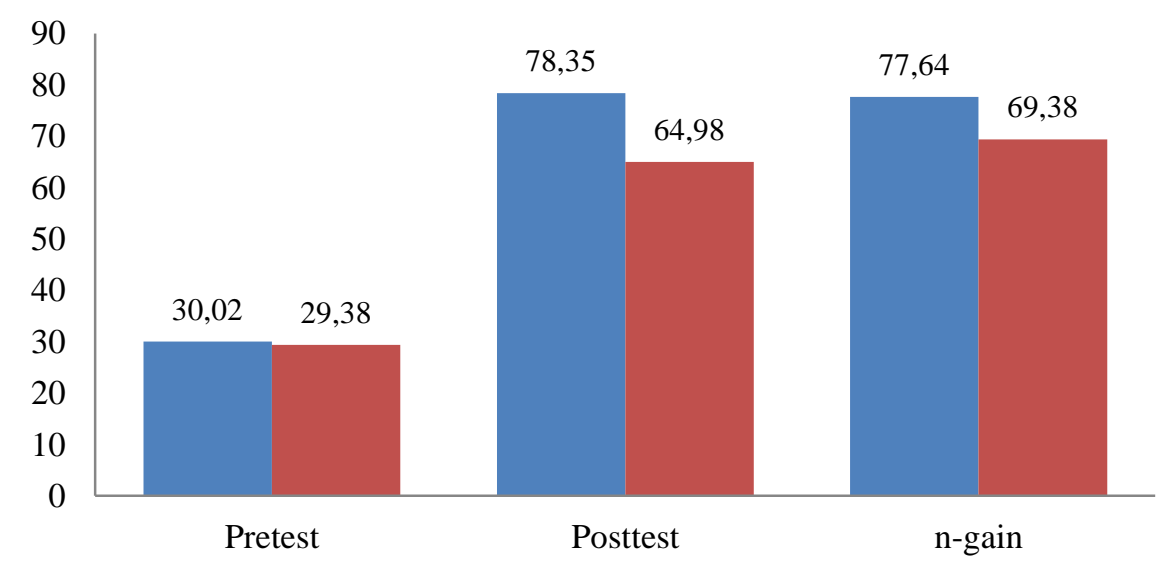

-Experimental Group $\quad$ Control Group

Figure-3. Comparison between experimental group and control group in learning outcomes

The compare means t-test of pre-test and normalization of gain (n-gain) showed (Table-3) a significant difference. It showed that the implementation of flipped classroom learning contributed to the improvement of students' learning outcomes. 
Table-3. The compare means $\mathrm{t}$-test of pre-test and $\mathrm{n}$ gain

\begin{tabular}{|c|c|c|c|c|c|c|}
\hline \multirow{2}{*}{ Mean } & \multicolumn{2}{|c|}{ Group } & \multicolumn{2}{|c|}{ Normality* } & \multirow{2}{*}{$\begin{array}{l}\text { Homogeneity ** } \\
\text { (exp-control) }\end{array}$} & \multirow[t]{2}{*}{ Significance } \\
\hline & Exp & Control & Exp & Control & & \\
\hline Pre-test & 30,02 & 29,38 & $\begin{array}{c}\text { Normal } \\
\mathrm{X}^{2} \text { count }(7,53)< \\
\mathrm{X}^{2}{ }_{\text {tab. }}(9,49)\end{array}$ & $\begin{array}{c}\text { Normal } \\
\mathrm{X}^{2}{ }_{\text {count }}(4,51) \\
<\mathrm{X}^{2} \text { tab. }(9,49)\end{array}$ & $\begin{array}{c}\text { Homogeneous } \\
F_{\text {count }}(1,19)< \\
F_{\text {tab. }}(1,44)\end{array}$ & $\begin{array}{c}\text { No Significance } \\
\text { Difference } \\
T_{\text {count }}(0,50)< \\
t^{-}{ }_{\text {tab }}(1,97)\end{array}$ \\
\hline n-gain & 77,64 & 69,38 & $\begin{array}{c}\text { Normal } \\
X^{2} \text { count }(4,96)< \\
X^{2} \text { tab. }(9,49)\end{array}$ & $\begin{array}{c}\text { Normal } \\
\mathrm{X}^{2}{ }_{\text {count }}(8,48) \\
<\mathrm{X}^{2}{ }_{\text {tab. }}(9,49)\end{array}$ & $\begin{array}{c}\text { Homogeneous } \\
F_{\text {count }}(1,41)< \\
F_{\text {tab }}(1,44)\end{array}$ & $\begin{array}{c}\text { Significance } \\
\text { Difference } \\
\mathrm{T}_{\text {count }}(3,26)> \\
\mathrm{t}_{\text {-tab. }}(1,98)\end{array}$ \\
\hline
\end{tabular}

Information:

${ }^{*}$ Chi square (Normal; $X^{2}{ }_{\text {value }}<X^{2}{ }_{\text {tab, }} \alpha=0,05$ )

${ }^{* *} F$ Test (Homogeneous; $F_{\text {count }}<F_{\text {tab, }} \alpha=0,05$ )

Using flipped classroom in learning process made student more flexible in determining learning time so it created an efficient time to use. They have learned the subject first at home before learning in class and it was encouraged them to express what has been learned in the discussion so that it has an impact on increasing the knowledge possessed (Tang et al., 2017). Learning with flipped classroom the teacher can create more time to interact with students in the class thereby increasing student participation (Unruh et al., 2016).

\subsection{Correlation between Self-confidence and Learning Outcomes}

Self-confidence is a belief in one's own abilities that will have an impact on learning outcomes. The results of data analysis showed that there was a positive and significant relationship (Table 4).

Table-4. The results of correlation between Self-confidence and learning outcomes

\begin{tabular}{|c|c|c|c|}
\hline $\begin{array}{c}\text { Correlation } \\
(r)\end{array}$ & $\begin{array}{c}\text { Coefficient } \\
\text { Determination }\end{array}$ & $\begin{array}{c}\text { Test of Significance * } \\
(\mathrm{r})\end{array}$ & Information \\
\hline 0,796 & 0,634 & $\begin{array}{c}\mathrm{t} \text {-count } \geq \mathrm{t} \text {-tab } \\
11,92 \geq 1,98\end{array}$ & Significance \\
\hline
\end{tabular}

The results of correlation between Self-confidence and learning outcomes in the experimental group showed there was a positive correlation with strong interpretation $(r=0.796)$ and correlation coefficient of 0.634 . This showed the ability of the variable Self-confidence in influencing student learning outcomes by $63 \%$ while $37 \%$ is influenced by other factors.

The results of regression between Self-confidence and learning outcomes in the experimental group (Figure4) showed that Self-confidence gave contribution on learning outcomes of students. The higher the level of Self-confidence the higher learning outcomes would be $(y=15,33+0,88 x)$. If one point was added, it would contribute to an increase in learning outcomes of 16.21 points.

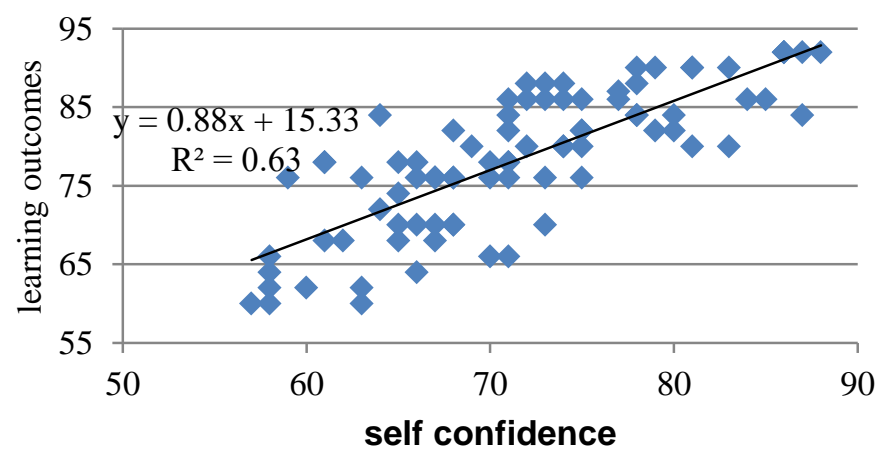

Figure-4. The graph of relationship between Self-confidence and learning outcomes

The positive relationship between Self-confidence and learning outcomes shows that the application of 
flipped classroom learning can make a significant contribution to improve learning outcomes. Students who have good Self-confidence will affect learning outcomes. Every student has good Self-confidence potential through learning flipped classroom.

\section{REFERENCE LIST}

Adnan, M. (2017). Perceptions of senior-year ELT students for flipped classroom: a materials development course. Computer Assisted Language Learning 30(4):204-222.

Balaban, R. A., Gilleskie, D. B., \& Tran, U. (2016). A quantitative evaluation of the flipped classroom in a large lecture principles of economics course. The Journal of Economic Education 47(4):269-287.

Brown, C. A., Danvers, K., \& Doran, D. T. (2016). Student perceptions on using guided reading questions to motivate student reading in the flipped classroom. Accounting Education 25(3):256-271.

Ceylaner, S. G., \& Karakus, F. (2018). Effects of the Flipped Classroom Model on Students' Self-Directed Learning Readiness and Attitudes towards the English Course. English Language Teaching 11(9):129-143.

Chen-Hsieh, J. S., Wu, W. C. V., \& Marek, M. W. (2017). Using the flipped classroom to enhance EFL learning. Computer Assisted Language Learning 30(2):1-21.

Everingham, Y. L., Gyuris, E., \& Connolly, S. R. (2017). Enhancing student engagement to positively impact mathematics anxiety, confidence and achievement for interdisciplinary science subjects. International Journal of Mathematical Education in Science and Technology 48(8):1153-1165.

Gall, M. D., Gall, J. P., \& Borg, W. R. (2003). Educational Research an Introduction. Boston: Pearson Education Inc.

Haghighi, H., Jafarigohar, M., Khoshsima, H., \& Vahdany, F. (2019). Impact of flipped classroom on EFL learners' appropriate use of refusal: achievement, participation, perception. Computer Assisted Language Learning 32(3):261-293.

Heuett, W. J. (2017). Flipping the math classroom for non-math majors to enrich their learning experience. Primus 27(10):889-907.

Hung, H. T. (2015). Flipping the classroom for English language learners to foster active learning. Computer Assisted Language Learning 28(1):81-96.

Johnson \& Graham B,. (2013). Student Perceptions of the Flipped Classroom. Columbia: The University of British Columbia.

Jones, J. P., McConnell, D. A., Wiggen, J. L., \& Bedward, J. (2019). Effects of classroom "flipping" on content mastery and student confidence in an introductory physical geology course. Journal of Geoscience Education 67(3):1-16.

Kim, D. (2017). Flipped interpreting classroom: flipping approaches, student perceptions and design considerations. The Interpreter and Translator Trainer 11(1):38-55.

Lax, N., Morris, J., \& Kolber, B. J. (2017). A partial flip classroom exercise in a large introductory general biology course increases performance at multiple levels. Journal of Biological Education 51(4):412426.

Maclellan, E. (2014). How might teachers enable learner self-confidence? A review study. Educational Review 66(1):59-74.

Malandrakis, G. (2018). Influencing Greek pre-service teachers' efficacy beliefs and self-confidence to implement the new 'Studies for the Environment' curricula. Environmental Education Research 24(4):537-563.

McLaughlin, J. E., White, P. J., Khanova, J., \& Yuriev, E. (2016). Flipped classroom implementation: a case report of two higher education institutions in the United States and Australia. Computers in the Schools 33(1):24-37.

Naccarato, E., \& Karakok, G. (2015). Expectations and implementations of the flipped classroom model in undergraduate mathematics courses. International Journal of Mathematical Education in Science and 
Technology 46(7):968-978.

Oney, E., \& Oksuzoglu-Guven, G. (2015). Confidence: A critical review of the literature and an alternative perspective for general and specific self-confidence. Psychological reports 116(1):149-163.

Rivera, E. (2017). flipping the classroom in freshman English library instruction: A comparison study of a flipped class versus a traditional lecture method. New Review of Academic Librarianship 23(1):18-27.

Tang, F., Chen, C., Zhu, Y., Zuo, C., Zhong, Y., Wang, N. \& Liang, D. (2017). Comparison between flipped classroom and lecture-based classroom in ophthalmology clerkship. Medical education online 22(1):19

Telbis, N. M., Helgeson, L., \& Kingsbury, C. (2014). International students' confidence and academic success. Journal of International Students 4(4):330-341.

Unruh, T., Peters, M. L., \& Willis, J. (2016). Flip this classroom: A comparative study. Computers in the Schools 33(1):38-58.

Youngkin, C. A. (2014). The flipped classroom: practices and opportunities for health sciences librarians. Medical reference services quarterly 33(4):367-374.

Zarrinabadi, N., \& Ebrahimi, A. (2019). Increasing peer collaborative dialogue using a flipped classroom strategy. Innovation in Language Learning and Teaching 13(3):267-276. 